EXPERIENCE REPORT: GRADUATE STUDIES AND SOCIAL WORK

\title{
The ABEPSS Thematic Research Groups on the relationship between graduate and undergraduate
}

\author{
Ana Paula Ornellas Mauriel \\ Fluminense Federal University (UFF)
}

The ABEPSS Thematic Research Groups on the relationship between graduate and undergraduate Abstract: The ABEPSS Thematic Research Groups have the strategic potential of resistance to the productivism and to the precariousness of the formation, either in undergraduate and/ or postgraduate studies, through research. The article presents, in the first moment, a recovery of the design of GTP in its original documents, its organic link with ABEPSS, with the Curricular Guidelines and with the political ethical project. Next, it shows the ways in which the GTPs have carried out their implementation, the challenges that accompany them to articulate undergraduate and graduate studies, and to build the approximation between the GTPs, the regional ones and the Academic Training Units.

Keywords: Research groups. Curricular Guidelines. Political Ethical Project. Postgraduate studies. 


\section{Introduction}

The Grupos Temáticos de Pesquisa (GTPs) [Thematic Research Groups] of the Brazilian Association of Teaching and Research in Social Work (ABEPSS) were created in 2010 at the National Meeting of Researchers in Social Work (ENPESS), held in Rio de Janeiro, with the purpose of serving as a base for the creation of networks of researchers and interlocutions between researches, in the sense of becoming a strategic space of resistance to productivism, isolation between researchers and the precariousness of training both in undergraduate and postgraduate studies, through the strengthening of research and of the production of knowledge in the area of Social Work. Several actions have been carried out since then by the coordinating commissions of the seven GTPs to implement this initiative in consecutive ABEPSS management.

The article is an adaptation of a lecture carried out in a Regional Workshop, whose theme was on the relationship between postgraduate and graduation and the strengthening of the GTPs in the current conjuncture of the intensification of the commercialization of higher education and destruction of rights, compromising key elements of the research and the conception of professional formation that is defended in the professional project of Social Work. In order to deal with the topic, the text presents, at the first moment, a recovery of the Thematic Research Group conception in its original documents, which necessarily goes through its organic link with ABEPSS, and then to understand this relation with the Curricular Guidelines and with the political ethical project. In the second moment, the text presents the main paths that the GTPs have undertaken to promote their implementation and the challenges that accompany them to articulate undergraduate and graduate studies and to build the approximation between the GTPs, the regionals and the Unidades de Formação Acadêmicas (UFAs) [Academic Training Units].

\section{The GTPs, the ABEPSS and the necessary articulation between Graduation and Post-Graduation}

The creation of the Thematic Research Groups (GTPs) occurred in 2008, from the inclusion of article n. 34 of the ABEPSS Statute on the constitution of Research Groups in the area of Social Work:

Art. 34. Thematic Groups - Research WG in the area of Social Work, enrolled in ABEPSS, are formed by researchers of specific themes that are sub-areas or specialties of knowledge of Social Work.

Sole paragraph: It is the responsibility of the research groups:

I - propose and implement strategies of articulation between groups and research networks with a view to strengthening the area of Social Work;

II - organize strategies to strengthen or resize the lines of research in the area of Social Work;

III- carry out permanent surveys of the researches developed and the thematic axes of each group;

IV- coordinate academic-scientific actions of the entity related to the axes of each thematic group;

$\mathrm{V}$ - propose to the board the structure of thematic organization for the National Meeting of Researchers in Social Work - ABEPSS (ABEPSS, 2008).

After the inclusion of this article in 2009, a first base document entitled "The consolidation of ABEPSS as an academic-scientific organization - a basic document for the formation of the Thematic Research Group (GTPs)" was prepared. Accumulating suggestions and observations from the discussions in the regional workshops. The revision of the document incorporated a set of proposals coming from democratic debates between Academic Training Units, Postgraduate programs and the National and Regional Board of ABEPSS. The ABEPSS National Seminar on Graduate and Research, held on November 26 and 27, 2010, at UFRJ, brought further subsidies for better design of the proposal, culminating in the presentation of a new document entitled "ABEPSS and the Strengthening of Research in the Social Service Area: the strategy of the Thematic Research Groups(GTPs)". The implantation of the GTPs took its first concrete step from the XIII National Meeting of Researchers in Social Work (ABEPSS) of 2010, held in Rio de Janeiro, when the colloquiums took place by thematic area, thus creating the seven GTPs of ABEPSS. These are: 1) Work, Social Issues and Social Work; 2) Social Policy and Social Service; 3) Social Work: Fundamentals, Training and Professional Work; 4) Social Movements and Social Work; 5) Agrarian, Urban, Environmental and Social Work Issues; 6) Social Service, Relations of Exploitation/oppression of gender, race/ethnicity, generation, sexualities; 7) Ethics, Human Rights and Social Work.

In the 2009 document, the creation of the GTPs is subsidized by Coordinating Commissions, which were elected in the Colloquiums under the XIII ABEPSS, but to be renewed every two years, along with the Board 
of ABEPSS, whose members should include: two coordinators, Indicated in the ABEPSS Colloquia, and a coordinator indicated by the Board of Directors of ABEPSS. The composition of these Coordinating Committees, as stated in the 2009 document, follows certain criteria:

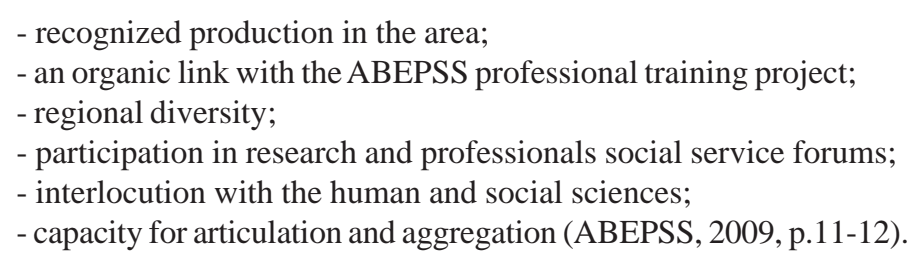

The construction of the GTPs consolidates an old concern of our area, whose historical possibility can only be unleashed at that moment, as a result of the accumulation of research and the maturation of the knowledge production of Social Service in the last thirty years. The conception of the Thematic Research Group places them there as strategic spaces of resistance against productivism, pressure and isolation that researchers are constantly subjected to meritocratic and increasingly intensified work.

The context of the creation of the GTPs is precisely that of intensifying the structural crisis and resulting from the consecutive neoliberal adjustments and counterreforms of education at all levels, particularly here considering the higher level, which brought over the years 1990 and 2000, an accelerated process of commercialization of education, the indiscriminate opening of distance courses and the lightening of vocational training (BRAZ; RODRIGUES, 2013). In this context, where the patterns of production and reproduction of capital and accumulation are more directly related to the construction of subjectivities, through values that reinforce the naturalization of social processes, competitiveness, pragmatism, utilitarian relations, new contradictions impose on educational processes that incorporate, from the perspective of the present time, selfresponsibility, entrepreneurship, flexibility, short-term relations, the technocracy of indexes and rankings, reinforcing with new ideological fuels the old cliché of which education is key to personal success in the market (GUERRA, 2013). Such changes have contributed to the formation of a culture of competitiveness and intellectual productivism, with a strong impact on the dynamics of social work postgraduate programs, on the strategic social direction of training that is to be consolidated in undergraduate studies, on the redirection of teachers'work and also in the university daily life (AMARAL, 2012).

Faced with these conditions, there is pressure to introduce positivist criteria and dynamics in the social area, which are logical given by other areas, especially the natural and exact sciences, which bring research dynamics that are foreign to the social area, given the nature of their objects and time requirements for research and results publication. Productivist logic ignores, for example, the importance of technical production, such as reports, social reports, advisory and consulting activities, which are considered important activities for all social workers. It is in this sense that the GTPs constitute a strategy of resistance to these corrosive processes, collecting cutting-edge debates, guiding relevant topics, feeding the debate of professional formation and exercise, feeding the publications of the area, stimulating the organization of research networks, encouraging the articulation with the research developed by Academic Training Units (UFA) and international research institutions, constituting the framework of ABEPSS, among other possibilities (ABEPSS, 2009) ${ }^{11}$. However, the differential of the GTPs in relation to the similar initiatives of associations of other areas is to seek the articulation of the postgraduation with the graduation. This specificity is due to the fact that the research dimension crosses all levels of vocational training - both undergraduate and postgraduate - and is intrinsically related to the interventive nature of the profession. In this sense, the GTPs constitute (or must constitute) "spaces that generate a synergy between undergraduate and graduate studies" (ABEPSS, 2009, p.2). Therefore, such a connection between undergraduate and graduate studies, in my view, can only be achieved without the mediation of the Curriculum Guidelines and the principles that apply in what we call the professional project of the Social Service or Ethical-Political Project.

The professional training of Brazilian social workers since the mid-1990s has a pedagogical project that contemplates a set of values and guidelines that surpass the idea of a purely vocational education, that give it the strategic direction and contemplates a certain profile of professional, which prioritizes the three dimensions of the profession: technical competence, theoretical criticism and ethical-political commitments. This professional profile, among other requirements, determines the need for a consistent theoreticalmethodological framework that allows a rigorous critical-analytical treatment, a set of values and ethical principles socially referenced with the workers and a technical-instrumental collection that serves as strategic reference for professional action (GUERRA, 2009). This profile corresponds to a formation aimed at understanding the real life dynamics of a generalist nature, with a horizon that provides elements and 
knowledge for the transformation of reality, always having as reference the reality of life and work of the exploited that suffer multiple forms of oppression.

The ABEPSS Curriculum Guidelines are a fundamental reference for guaranteeing this training, since it is based on a set of inseparable knowledge, which translate into the nuclei of foundations that constitute Vocational Training, thinking of them as a vision of totality.The Law no. 8662/1993, which regulates the profession of Social Work, requires the social worker to make research a constituent element of his professional work, as a precondition of competent and qualified professional practice, since it recognizes and emphasizes the investigative nature of Professional skills (BRAZIL, 2011). More than a posture, the investigative character is constitutive of most of the professional competences / attributions (GUERRA, 2009). In other words, training is an endless process that does not end in undergraduate or even postgraduate studies, but requires constant updates as a form of individual commitment (inscribed in the Code of Ethics) and collective (recognized by the category entities) with the quality of services provided to society (BRAZ; RODRIGUES, 2013).

The research consequently assumes a decisive role in the achievement of an academic statute that makes it possible to combine training with professional training, indispensable conditions both for a qualified professional intervention and for the expansion of the intellectual and bibliographic patrimony of the profession, which has been specially produced, but not exclusively, under the stricto senso graduate course. It is important to emphasize that Social Service research has been developed strongly for many years in undergraduate studies. However, postgraduate vocation and leadership in the process of knowledge production in the last decades is undeniable. Historically, the primacy of the interventionist prescription of the profession did not ensure that its objects of intervention gained statutes of a specific area of knowledge. What allowed the Social Service to become an area of knowledge institutionally recognized by the CNPq (National Counsel of Technological and Scientific Development) was, on the one hand, the emergence of an intellectuality that can be linked, as a priority, to the research and production of knowledge (NETTO, 1996) and, on the other hand, processes of aggravation of the social question and the complexity of the state-society-market relationship in the post-64 context, which demanded that Social Service seek in the social and human sciences the contribution to the construction of more qualified answers (CARVALHO; SILVA, 2005). It is in this scenario that the Brazilian Social Service is asked to incorporate research as an instrument of knowledge and intervention over the realism.

However, in the process of maturation of the Brazilian Social Service (NETTO, 1996), in the transition from the 1980s to 1990, with the efforts of ruptures with traditional conservatism, the Brazilian Social Service gained visibility in Brazilian society, through its Representative publications, publications of their own bibliography and the positions they assumed in the planning and management of public policies ${ }^{2}$

Social Service ends in the 1990s and enters the 21 st century confronted with the transformations unleashed by the crisis and its responses on the international scene, by neoliberalism and the counterreformation of the State in Brazil and its impacts on the world of work and social policies, bringing new challenges for vocational training and intervention. It is on these issues that the GTPs are created and bring with them the task of strengthening Social Service as an area of knowledge, but without elitiating or hierarchizing this production of knowledge, giving exclusivity to the graduate. Therefore, the other essential mediation to strengthen the relationship between undergraduate and postgraduate studies is the ethical-political project, since we understand that "the production of knowledge itself directs and guides the directions of professional formation, provides the theoretical outline of the Ethical-political project and the construction of the professional profile that is desired" (BRAZ; RODRIGUES, 2013, p.258).

We start from the understanding that the components that materialize such a project in the socio-historical process of the profession are the ethico-political principles and values, the theoretical-methodological matrix in which it is anchored, the radical critique of the current social order, besides the struggles and positions politicians accumulated by the category through their collective organizations and other forms of political organization allied to the movements and more progressive sectors of Brazilian society:

The ethical-political project has at its core the recognition of freedom as the central ethical value - the freedom conceived historically, as a possibility to choose between concrete alternatives; Hence a commitment to the autonomy, emancipation and full expansion of social individuals. Consequently, the professional project is linked to a societal project that proposes the construction of a new social order, without domination and/or exploitation of class, ethnicity and gender (NETTO, 1999, p. 104-5 apud TEIXEIRA; BRAZ, 2009, p. 6).

So it was no coincidence that the GTPs were created precisely in the ABEPSS where the theme was "Capital Crisis and Knowledge Production in Brazilian Reality: research for what, for whom and how?", given that in the face of the worsening crisis of the capital and the exacerbation of the expressions of the "social 
question", it is not possible to think of research and the production of knowledge as sources of renewal for training, without being socially referenced, without being tied to the struggle for rights and without losing sight of the direction of the construction of human emancipation, therefore critical. This conception of GTPs that reinforces the relation of the research in the graduation and not only in the post and its connection with values and professional principles are present in the document of 2009 that gives origin to the GTPs.

\section{Challenges of the deployment of the GTPs: balance and perspectives ${ }^{3}$}

Starting from the following ABEPSS administration, once the coordinating commissions have been elected at the ABEPSS 2010 colloquia, there has been a process of implementation of the GTPs, which in a very different way have sought to assure the premises and objectives that are the basis of their constitution, which more effectively has sought: to know and socialize the "state of the art" of each thematic area; approach, stimulate and strengthen links between the researchers and participate more organically in the ABEPSS organization.

The November 2012 ABEPSS GTP information document shows a first review of this construction. In this publication the objective was to give visibility to the activities that involved the implementation of the GTPs in the 2011-2012 management. This document shows us that, in terms of conception, there is a version that is more focused on the organization of research in graduate school, less focused on integration with graduation. In terms of design, it is stated:

Recognizing them as necessary for theoretical reflection, the Thematic Research Groups show itself as a dynamic, stimulating and effective space for the elaboration, production and circulation of knowledge. Organized around researchers in the areas of knowledge of Social Service and related areas, the Thematic Research Groups bring together specialists to deal with topics of social relevance, constituting themselves in nuclei capable of disseminating information on specific themes, promoting deeper debates on the cuttingedge themes of professional interest and demands of the progressive forces of society. It also promotes the integration between the research developed in the Programs and the lines of research considered relevant to the area, stimulating and strengthening the instances of the debate on scientific policy in the country, alongside and in articulation with other scientific associations. The Research Groups, as the name implies, are formed by researchers, groups, nuclei, area networks and related areas, to address issues of social relevance. These groups have their own life and autonomy, but are organically linked to ABEPSS, and they must be able to disseminate productions; promote debates and establish dialogue between researchers (ABEPSS, 2012, p. 9).

This has had direct repercussions on the purposes of the GTPs, which, in the document, return to the original characteristics of Article 34 of the ABEPSS Statute, 2008, that is, that were conceived before the accumulations of the extensive discussions in the regional and between the programs of post which culminated in the 2009 document that gave rise to the GTPs in the ABEPSS of 2010. And one of the main accumulations gained in the debates was precisely the indication that the GTPs should serve as a means of strengthening the relationship between undergraduate and postgraduate through research and the production of knowledge. This means, on the one hand, that in the first moment of construction of the GTPs (first consecutive management of ABEPSS 2011-2012) there was a need for the GTPs to turn inward, to self-organize, indicating a phase of recognition of this strategy and to face the first challenges, such as the division of the seven thematic axes, the construction of the menus of each of these axes, the construction of the work dynamics of the coordinating commissions, which had different profiles and locations and the relationship with ABEPSS itself. On the other hand, that the relationship between graduate and undergraduate is one of the most challenging elements not only to make the GTPs operational, but also to build the capillarity of ABEPSS itself. That is, the GTPs are not immune to the determinations undergone by graduate studies, research and higher education as a whole. Determinations that always reduce "the possibility of guaranteeing the essential element of what qualifies Social Service as a profession linked to the interests of the working classes, what gives it a strategic social direction, that is, a question of the method of analysis of the Reality, but reinforcing its procedures and normative and practicals" (AMARAL, 2012, p. 232).

It is important to note, however, that there was a general construction movement, an advance from the initial starting point in 2010, by all GTPs. The main activities that demonstrate this are: the accumulation on the knowledge of the "state of the art" of each thematic area of the GTPs and their socialization in the temporalis, in the colloquies; Attempts to build and strengthen links between researchers (as); Participation in a more organic way in the ABEPSS organization; The very reissues of the menus that have been expanded and 
included topics related to its first version, as a result of collective discussions in the colloquia. All these activities made it possible to perceive an increase in the number of participants in the GTP colloquia in ABEPSS and in the GTP events in general; The growth of groups and research centers in the thematic areas of the GTPs, as well as publications and papers at ABEPSS events, as well as the presence of themes in research lines and postgraduate subjects.

With regard to the survey of the state of the art of knowledge production, the strategies used have been, for the most part: Consultation in the thesis and dissertations bank of CAPES; Consultation with important periodicals in the area; Consultations to the sites of the graduate programs of the area; Consultation of the research groups registered in the directories of the CNPq groups; Observation of the disciplines taught in the area's postgraduate programs; Consultation of the Annals of the CBAS and the annals of the past ABEPSS, besides analysis of the work of the ABEPSS in the current management.

Some GTPs have made further progress in addressing the issue of training and in conducting its thematic axis in the Guidelines. The main strategies presented (still to be carried out, others in the initial stages of realization) in the reports were: the preparation of a bibliographic reference on the subject of its GTP; research on the development of the GTP subject in the Menus, Programs and Bibliographies of the subjects of Graduation and Post-Graduation in the Academic Training Units; to analyze the contents related to the subject of the GTP from the report of the "evaluative research on the implementation of the curricular guidelines of the Social Work course" carried out by ABEPSS, published in Temporalis n. 14; to identify the production carried out by the Research Groups of the Graduation and Post-Graduation of the area and related; also encompassing the researches in the field of professional work and the Social Service stage linked to the thematic area of the GTP; to carry out a survey of the written Trabalhos de Conclusão de Curso (TCCs) [Term Papers] on the subject of the GTP in the scope of Social Work; in the field of professional practice, to analyze the institutional demand for Social Service work in the thematic area of the GTP (in some GTPs this is easier, such as social movements or agrarian issues, for example, but social policy is already more difficult because the scope is very broad, involving different policies and different spheres of action).

With regard to the main strategies to bring the GTPs closer to regional and UFAs, surveys of $\mathrm{CNPq}$ directory research groups, surveys and ABEPSS regional graduate program lines were carried out (this has been appearing in recent years). Reports and systematizations in the ABEPSS Colloquiums, many already identifying which Academic Training Units correspond to the research groups in their thematic axis); It was suggested to form a partnership with the Regional Councils of Social Service and participation of its commissions (depending on the thematic area of the GTP); A training course for teachers, students and social ...there is pressure to introduce positivist criteria and dynamics in the social area, which are logical given by other areas, especially the natural and exact sciences, which bring research dynamics that are foreign to the social area, given the nature of their objects and time requirements for research and results publication. workers on the subject of the GTP was suggested (in this initiative it was suggested to consider a possible integration with itinerant ABEPSS).

Concerning the socialization of the data and the work carried out by the coordinating commissions, the actions already carried out, the presentations in the graduation colloquiums and in the events of the GTPs, actions that contributed to a process of qualitative densification in the colloquiums of the GTPs in the ABEPSS, with a commitment to a post-ABEPSS publication, particularly through publication in the Temporalis magazines. And as suggestions for improving the dissemination and socialization: the creation of a page on facebook (GTP of race/ethnicity, gender, sexualities, generation already indicated the page); video creation; proposal that ABEPSS send to the UFAs the material systematized by the GTPs, which have not yet been published, considering that these data are difficult to access; and, finally, the need to invest in the permanent systematization and registration, to be kept with ABEPSS, of everything that is built in each management by the GTPs, guaranteeing the operational continuity of the GTPs, indicating the reports as one of the main means for this.

Many of these strategies and activities suggested or carried out, however, presented or present difficulties. These challenges include some of the issues and challenges that are being discussed between the GTPs and between them and the National ABEPSS. A first element is the role of the coordinating committees, which are still very much centralized in the GTP's dynamics, even though they have been expanded in the process with 
new members and representatives, due to the tasks they have been carrying out in the organization of ABEPSS and the demands for approximation with the regional ones (participation in the national and regional workshops, besides the activities of monitoring the researches and productions of the area, etc., as we saw earlier).

This is closely linked to the daily excessive work in academic routines, often leading to the discontinuity in the development of the tasks of coordinating commissions, because today there is a composition diversity of the coordination and the of the GTPs themselves. There are three, four, five, or even more members inscribed as coordinated, or even as extended coordinations, with different forms of functioning of the same, and also different perceptions of how the link between researchers and GTPS occurs, which leads us to second point. Another issue still under discussion between the GTPs and ABEPSS is who can participate in the GTPs, which is central to advancing the activities of GTP coordinating commission. In the 2012 document, those who could compose the GTPs were: "Social Workers, teachers, Social Service researchers and related areas of public and private universities that already have production related to the subject, as well as those who wish to articulate with other research in one of the seven structuring axes of the Thematic Research Groups- GTPs" (ABEPSS, 2012).

This definition is very broad, but it fits in with the idea of a group with a more academic profile, something that is not yet agreed among the GTPs, as some think of broadening ties to social movements, other entities or even other areas. That is, progress has already been made in relation to that first version built in 2012 .

The consolidation of an organic articulation between the researchers supposes the deepening and investment in some fronts that deserve to be analyzed and discussed collectively, be it between the GTPs, or with the National Executive Board of ABEPSS and its regional and with wider academic communities. Some of these fundamental issues have already been debated and directly reverted on how to consolidate this participation and the expansion of the relations of the GTPs with the regional ones and with the Academic Training Units. A first key element is in the relationship between the GTPs themselves. There is, in some GTPs, a need to approximate their themes within the GTP itself. For example, in the case of the GTP of social service, relations of exploitation/oppression of gender, race/ethnicity, generation, sexualities, whose broad and diverse themes end up defining thematic sub-themes that have been worked separately, despite the effort of the respective coordinating committees to articulate them. There is also a need for an approximation between the GTPs, which are still working away from each other, occupied with their own dynamics, needing to have more articulation, which involves building joint program objectives but also common themes. In this case, the question that has been considered is not the concern with isolation due to a hierarchy between researchers, that is, between the coordinating committees that represent ABEPSS and the researchers that form the GTPs, even considering the weights of / The coordinators who say that the regional meetings and the ABEPSS are insufficient to form a dynamic of the groups. However, the main question about the relationship between the GTPs is how to establish the articulation between their themes, programs and menus, in order to articulate them as the nuclei of foundation that make up the Curricular Guidelines. For example, how to think about the generation axis (child and adolescent, young, old) without articulating with the social policies that will materialize their rights? How to think the issue of women or GLBTT without articulating with the social movements and struggles that present themselves today? How to think about social policies without articulating with work and social issues? It is in this sense that there are indications for future joint actions between the GTPs, with events whose themes can bring together researchers from different groups to think about the same problem, or more broad themes, collaborating to advance and mature debates on several fronts, strengthening the area of Social Service as a producer of knowledge.

Another element is the nature of the organic linkage of researchers of the area to the GTP, which, in my view, does not depend exclusively on communication strategies or only on-site activities that approach them, but, above all, strategies that allow the knowledge of the objectives and challenges for research in the thematic area of the GTP. That is, updating the "state of the art" of productions should lead to what should be prioritized as the political direction to be proposed in the thematic axes. This direction is a key element to ensure a broader dialogue between Social Service researchers and Social Service areas, guaranteeing pluralism, but with hegemony. GTPs could thus function as a space that has a margin of flexibility, which can also serve as the gateway to ABEPSS for those who are not yet close to the entity yet still being part of the entity.

That is, the social direction that is the basis of the constitution of the GTPs is one of the structuring axes of a programmatic articulation between potential pairs. Because in carrying out the "state of the art" of their productions, the GTPs, have been identifying traces that indicate different social direction from those put by our professional formation project, expressing the contradictions of the capital crisis context and the conservative responses to it. Therefore, if we think that since its origin the GTPs are strategically spaces for the strengthening of the ABEPSS, and consequently, they should strengthen the vocational training project that we defend. 
A final element concerns what is meant by "undergraduate research" or research dimension. While GTPs are necessary, if we want to strengthen the relationship between undergraduate and graduate students, to value how and where knowledge production is done and research in undergraduate and professional spaces (this leads us to curricular and pedagogical course projects, including, how research has been considered as a discipline, for example) and what is the relation of these productions with each thematic axis in the foundations of the Curricular Guidelines.

\section{Final considerations}

The current situation (the end of the 2015-2016 administration) marks another moment in the process of construction of the GTPs, different from the initial one, because from the maturation and discussions resulting from the participation in ABEPSS, regional events and internal work of the coordinating commissions, other elements become part of the concern of both the coordinating commissions and ABEPSS in order to give more capillarity and life to the GTPs. GTPs can not be thought of and treated as separate spaces of the ABEPSS or displaced from their spaces, in that sense this was the construction sought by the latter management (2015-16), for example, by bringing closer the coordinating commissions of the ABEPSS organization. This is something new since it is the first ABEPSS in which the GTPs have been working together with the National Directorate of ABEPSS throughout the academic-scientific construction of the event. However, previous experiences, even if more limited, have been important and fundamental steps to move forward in this direction. There is no denying that each edition of ABEPSS, through the direct interaction of the National with the various coordinations, sometimes involving researchers of the GTPs in the colloquia and now in the thematic tables, was important to ensure the coherence and the theoretical quality of the event.

At the last ABEPSS, held from December 4 to 9, 2016 in Ribeirão Preto, in addition to increasing the participation of the GTPs in the general organization phase of the event (from the discussion of the inscriptions and emphases of the works to the dynamics of evaluation of the works, choose arbitrators, thematic advisors, drafting of letter to arbitrator and advisors, support in the organization of thematic sessions), the coordinating committees were involved in the whole process of designing the event, especially participating as representatives of the scientific committee. During the event, their spaces were expanded with the generalization of the Thematic Tables of each GTP (which had already been tested in the previous ABEPSS held in Natal with the GTPs of Social Movements and Social Work). Until the XIV ABEPSS, in Natal, the GTPs only held the Colloquiums, where they divided the time among the discussion of relevant themes of their respective thematic axis before the conjuncture. As of the XV ABEPSS, in addition to the GTP Colloquiums, the Thematic tables were included, whose objective is precisely to be able to deepen the discussion of relevant themes of the thematic axis of the GTP4.

Another innovation that emerged from the last ABEPSS is the creation of a new Thematic Group, the GTP Social Service, Generation and Social Classes, as a result of the dismemberment of the generation of the GTP Social Service, relations of exploitation/oppression of gender, race/ethnicity, generation, sexualities, which now happens to be named GTP Social Service, relations of exploitation/oppression of gender, race/ethnicity and sexualities. The emergence of this GTP was the fruit of discussions and maturation that has been taking place since before the XV ABEPSS, in $2014^{5}$.

The GTPs, however, can not stop here, they need the involvement and participation of the researchers in different activities, according to their program and challenges that are imposed to research and training in the area both in graduate and undergraduate.

Finally, I understand that the recognition and relevance of research in the area of Social Service was a fundamental achievement undertaken in the last decades and the potential of the GTPs to articulate the dimensions of teaching-research-extension is real, obviously having an understanding of the dimensions of their actions, challenges and strategies that face each ABEPSS management.

In the light of these considerations, I hope that the text is a record that can contribute to systematizing the actions of the ABEPSS GTPs and that can initiate a dialogue about the rooting and dissemination of the GTPs in the academic and professional daily life of the regional boards of ABEPSS and of the Academics Training Units.

\section{References}

ASSOCIAÇÃO BRASILEIRA DE ENSINO E PESQUISA EM SERVIÇO SOCIAL. A ABEPSS e o Fortalecimento da Pesquisa na Área de Serviço Social: a estratégia dos Grupos Temáticos de Pesquisa (GTPs). Gestão 2009-2010. Rio de Janeiro, 2009. Mimeo. 
Estatuto da Associação Brasileira de Ensino e Pesquisa em Serviço Social. 2008. Disponível em:

< http://www.abepss.org.br/arquivos/textos/arquivo_201604041530365473870.pdf >. Acesso em: 10 nov. 2016.

. Grupos Temáticos de Pesquisa. GTPs ABEPSS. Informativo gestão 2011-12. Juiz de Fora, novembro, 2012. Mimeo.

AMARAL, N. S. A política Nacional de Pós-Graduação e suas relações com o Serviço Social. Revista Katáysis, Florianópolis, v. 15, n. 2, p. 230-238, jul./dez. 2012.

BEZERRA, C. S. et al. Relatório de Gestão do Grupo Temático de Pesquisa Questão Urbana, Agrária e Ambiental. Gestão 2013-2014. ABEPSS, 2015, mimeo.

BRASIL. Código de Ética do/a assistente social. Lei 8.662/1993 de regulamentação da profissão. 9. ed. Brasília: CFESS, 2011. Disponível em: <http://www.cfess.org.br/arquivos/CEP2011_CFESS.pdf〉. Acesso em: 10 out. 2016.

BRAZ, M.; RODRIGUES, M. P. O ensino em Serviço Social da Era Neoliberal (1990-2010): Avanços, Retrocessos e Enormes Desafios. In: SILVA, J. F. S.; SANT’ANA, R. S.; LOURENÇO, E. A. S. (Orgs.). Sociabilidade Burguesa e Serviço Social. Rio de Janeiro: Lumen Juris, 2013.

CARVALHO, D. B. B.; SILVA, M. O. S. Das origens à atualidade da profissão: a construção da Pós-Graduação em Serviço Social no Brasil. In: CARVALHO, D. B. B.; SILVA, M. O. S. (Orgs.). Serviço Social, pós-graduação e produção de conhecimento. São Paulo: Cortez, 2005.

GUERRA, Y. A dimensão investigativa no exercício profissional. In: CFESS. Serviço Social: Direitos Sociais e Competências Profissionais. Brasília: CFESS/ABEPSS, 2009.

GUERRA, Y. Formação Profissional em Serviço Social: Polêmicas e Desafios. In: SILVA, J. F. S.; SANT’ANA, R. S.; LOURENÇO, E. A. S. (Orgs.). Sociabilidade Burguesa e Serviço Social. Rio de Janeiro: Lumen Juris, 2013.

NETTO, J. P. Transformações societárias e Serviço Social - notas para uma análise prospectiva da profissão no Brasil. Serviço Social e Sociedade, São Paulo, ano 17, n. 50, p. 87-132, abr. 1996.

TEIXEIRA, J. B.; BRAZ, M. O Projeto Ético-Político do Serviço Social. In: CFESS. Serviço Social: Direitos Sociais e Competências Profissionais. Brasília: CFESS/ABEPSS, 2009.

\section{Notas}

1 It is worth noting that "the character of the GTP is not research execution, but rather to stimulate and foster the exchange between researchers and to socialize the researches, either the ones in progress or the ones that have already been executed"' (BEZERRA et al, 2015). ${ }^{1}$

2 "Since 1984, Social Service has been recognized as a research area by the National Council for Scientific and Technological Development (CNPq), a fact that not only legitimized it institutionally in the field of development and evaluation agencies, but also helped to make possible the Study of the problematics of reality and its relation with the production of knowledge" (AMARAL, 2012, p. 237).

3 Part of the balance presented here was based on systematization carried out on the information contained in the 2013-14 Management Reports of the Work, Social Issues and Social Work GTPs; Social Policy and Social Service; Social Work: Fundamentals, Training and Professional Work; Social Movements and Social Service; Agrarian, Urban, Environmental and Social Service; Social service, exploitative relations / oppression of gender, race/ ethnicity, generation, sexualities; Ethics, Human Rights and Social Service, delivered to the ABEPSS National Directorate between March and August 2015.

4 Thematic tables: Social Movements and Social Work: Historical rescue of the 80 years of the profession and contemporary challenges of the relationship of Social Service with social movements (GTP Social Movements and Social Service); Social relations of oppression and exploitation: mediations for formation and professional exercise (GTP Social Service, Relations of Exploitation/Oppression of Gender, Race/ Ethnicity, Generation, Sexualities); Social Service, Pluralism and Human Rights: some reflections in the face of professional training and exercise (GTPEthics, Human Rights and Social Service); The ruin of work and the challenges for Social Work (GTPWork, Social Issues and Social Work); The need for theoretical-methodological and ethical-political support of the Curriculum Guidelines/1996 in the context of the advancement of conservatism in society and in the profession (GTP Social Service: Foundations, Training and Professional Work); Urban, Agrarian and Environmental Question: reflections on the production in the area and challenges in the light of the Curriculum Guidelines (GTP Agrarian, Urban, Environmental and Social Service Questions); State and Social Policy - foundations and current contradictions (GTP Social Policy and Social Service).

5 Considerations about the dismemberment of the thematic generation of GTP Social Service, relations of exploitation/oppression of gender, race/ ethnicity, generation, sexualities were presented at the GTP Colloquium in 2014 and redistricted at the ENPESS in 2016, referrals from the Colloquium were taken to Assembly of ABEPSS held on 12/12/2016, which approved the creation of the new GTP.

\section{Ana Paula Ornellas Mauriel}

apmauriel@gmail.com

$\mathrm{PhD}$ in Social Sciences from the State University of Campinas (Unicamp)

Professor of the School of Social Service and the Post-Graduate Program in Social Work and Regional Development of the Fluminense Federal University (UFF) 
Fluminense Federal University (UFF)

Professor Marcos Valdemar de Freitas Reis st., block E, room 511

University Campus of Gragoatá

São Domingos - Niterói - Brazil

Zip code: $24.210-510$ 